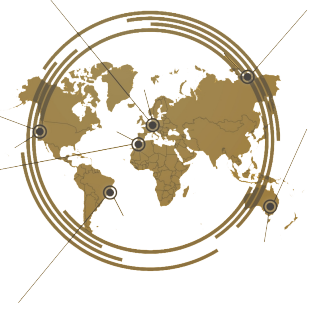

\title{
Incorporating Hijaiyah Sounds in English Pronunciation Class: Students' Perception
}

\author{
Rosalin Ismayoeng Gusdian*, Riski Lestiono \\ English Language Education Department, University of Muhammadiyah Malang, Indonesia
}

Indonesian students still find it perplexing to acquire English pronunciation as both Bahasa as their mother tongue and English do not share equivalent phonological and phonetic systems. Meanwhile, Arabic (in this case is their Hijaiyah sounds) is proven to share some phonological resemblance to some English sounds. Therefore, it is the aim of the study to investigate the student perception of the implementation of Hjaiyah sounds in their English pronunciation class. The study employed a descriptive research design as the approach. The participants of the study were 36 students of the English Study Program in the academic year of 2019/2020. These participants were third-semester students undertaking their Intermediate Speaking class. Questionnaire and interview guide were utilized as data instruments. In collecting the data, some procedures including distributing the questionnaire and conducting the interview were carried out. In data analysis, the data from the survey were transformed into a percentage to obtain a more general image of the data description. The data from the interview were also transcribed. Finally, the findings were examined and discussed using both narrative and numerical description. As a result, this study has confirmed that the implementation of Hijaiyah sounds in teaching English pronunciation is perceived positively by the students.

Keywords: Hijaiyah sounds, pronunciation, student perception

\section{INTRODUCTION}

It has generally been accepted that many Indonesian students still find it a tedious journey

OPEN ACCESS

ISSN 25033492 (online)

${ }^{*}$ Correspondence:

Rosalin Ismayoeng Gusdian

rosalingusdian@umm.ac.id

Received: 10th February 2020

Accepted: 22nd March 2020

Published: 7th April 2020

Citation:

Gusdian Rl and Lestiono R (2020)

Incorporating Hijaiyah Sounds in

English Pronunciation Class: Students'

Perception.

J. Eng. Educ. Society. 5:1.

doi: 10.21070/jees.v5i1.380 to acquire English pronunciation (Donal, 2016; Lestiono and Gusdian, 2017; Gusdian and Lestiono, 2018; Anam, 2018; Sundari, 2018; Andi-Pallawa and Alam, 2013). Such a tenet is plausible to acknowledge as both Bahasa and English do not share comparable phonological and phonetic systems Dardjowidjojo (1978). There are various phonological features that exist in one language but not in the other. In the case of diphthongs, for example, Donal (2016) revealed that due to lack of knowledge of sound the systems in English, many students encounter complications in producing several English diphthongs, especially the gliding sound of /au/ such as found in 'brown', 'pound', and 'round'. In another case, Sundari (2018) found that different sound distribution present in both Bahasa and English has become a contributing factor to phonological constraints faced by Indonesian students in producing accurate English pronunciation. For instance, letter ' $c$ ' in English is distributed into several distinctive sounds like / $\mathrm{k} /$ in 'cat', /s/ in 'rice', /tj/ in 'cheap', or even not representing any sound such as indicated the words 'track' and 'black' respectively. It is also unveiled that some consonant sounds in English are not present in Bahasa (Lestiono and Gusdian, 2017; Sundari, 2018; Gusdian and Lestiono, 2018). 
These consonant sounds comprise both dental consonants $/ \theta /$ and /ð/, and the palato-alveolar / $\int /$.

In the studies as mentioned earlier, it is explained further that due to the non-existence of these particular sounds, a number of Indonesian students often make mistakes in pronouncing words containing such sounds. Instead of producing accurate English sounds, they apply similar sounds that exist in Bahasa. For instance, many of the students pronounce 'the' as /d/, not /ð/ and 'mother' as /madr/ not /mað:/. From the result, it can be assumed that the students apply similar sounds that exist in Bahasa, such as /d/ which resembles /ð/, and /s/ which resembles /ð/ and / $\int /$.

There may not have been many studies investigating ways in coping with students' difficulty in their English pronunciation; the only study that comprehensively discusses such an issue is found in Lestiono and Gusdian (2017). Inspired by the phonological sameness of English and Arabic (Hijaiyah) consonants, this study brings explicitly about the notion of making use of Hijaiyah sound to assist students in producing English sounds. In their findings, it is revealed that some consonant sounds $\left(/ \theta /, / ð /\right.$, and $\left./ \int /\right)$ that exist in both languages may serve as a bridge for Indonesian students to produce correct pronunciation when speaking in English. It is due to the fact that most Indonesian students are Muslims and familiar with Hijaiyah sounds; therefore, they are assumed to develop fairly phonological knowledge about the designated sounds.

Following the piloting study, the researchers then conduct series of studies about the implementation of Hijaiyah consonant sounds to all levels of education in Indonesia, namely university, high school, and elementary school Gusdian and Lestiono $(2018,2019)$. Further, the findings of the Hijaiyah sound implementation in the university and high school levels show that the targeted sounds $\left(/ \theta /, / ð /\right.$, and $\left./ \int /\right)$ are mostly infused in a typical controlled pronunciation class like short passage reading aloud, sound imitation and pronunciation drilling. Besides, students are also introduced to the phonetic transcription of the designated sounds; it is intended to raise students phonological awareness of the sounds they learn. Pronunciation games such as tongue twister and sound identification games are also employed here. Meanwhile, the finding revealed in the elementary school students is somewhat different from that of the previous education levels. Such an implementation is mostly incorporated in games, songs, and other typical activities entitled for English for Young Learners' activities.

Apart from the series of studies mentioned earlier, how students perceive the implementation of Hijaiyah sounds in their English classroom activities is deemed imperative. It is because knowing student perceptions has become an essential determinant to understand student behavior towards the implementation of Hijaiyah sounds in their class. However, none of the previous studies discuss the students' perception on the usage of Hijaiyah sounds. Therefore, to bridge the gap, the primary purpose of this study is to find out the student perception towards the implementation of Hijaiyah sounds in their English pro- nunciation class.

\section{METHOD}

This study was conducted from September to November 2019 at a private Islamic university in Malang. A descriptive research design was embraced to explore how Indonesian students at the university level perceive the implementation of Hijaiyah sounds in their pronunciation class. According to Atmowardoyo (2018), in terms of its data collection procedures, descriptive research comprises several sub types of research methods such as correlation study, survey, and qualitative study. Consequently, a descriptive study may involve qualitative or/and quantitative analysis. The participants of the study were thirtysix students of the English Study Program in the academic year of 2019/2020. These participants were third-semester students undertaking their Intermediate Speaking class. In their speaking class, they also learned some pronunciation materials-one of them was about making use of Hijaiyah sounds to produce some English sounds.

Survey and interview were utilized as data collection techniques. The questionnaire developed in this study was a Likertscale type, in which the research participants were to choose how much they agree or disagree with the statements. The scalar item itself ranged from 1 (extremely disagree) to 5 (extremely agree). Besides, the items in the questionnaire were carefully designed to comply with the research question of the study. Some questions were repeated in different wordings to check the consistency of the participants' answers. Then, to check the validity of the questionnaire, face validity was carried out. Seven participants took part in the interview; these seven students were chosen randomly from all thirty-six participants as their representatives.

The data collection procedure covered preparing and distributing the questionnaire and conducting the interview. Then, in the data analysis, the data from the survey were transformed into a percentage to obtain a more general image of the data description. Also, all of the data from the interview were transcribed. After gaining all of the results, the findings were examined and discussed using both narrative and numerical description.

\section{RESULTS AND DISCUSSION}

The findings of the study fall into three main subtopics of discussion. The first discussion reveals the student perception towards English pronunciation itself. Then, the second one seeks further on how the students perceive the use of Hijaiyah sounds to bridge their English pronunciation lessons. Lastly, the investigation digs out the student perception on whether or not Hijaiyah sounds can be continuously employed as a new method to teach English pronunciation to Indonesian students. 


\section{Student Perception on English Pronunciation}

The findings from the questionnaire about how the students perceive English pronunciation are depicted in Table 1.

TABLE 1 || Student Perception towards English pronunciation

$\begin{array}{llllll}\text { Statement } & \mathbf{1} & \mathbf{2} & \mathbf{3} & \mathbf{4} & \mathbf{5} \\ \begin{array}{l}\text { English pronuncia- } \\ \text { tion is challenging for }\end{array} & 0 \% & 0 \% & 8.3 \% & 61.1 \% & 30.6 \% \\ \begin{array}{l}\text { Indonesian students } \\ \text { Indonesian students }\end{array} & 0 \% & 0 \% & 13.9 \% & 66.7 \% & 19.4 \% \\ \text { often face some diffi- } \\ \text { culties when learning } \\ \text { correct English pronun- } \\ \text { ciation }\end{array}$

In Table 1, it is reported that most of the students agree that Indonesian students find English pronunciation troublesome. A consistent answer is clearly seen in both statements in which the majority of the students choose scale 4 , indicating that they favor the statements. Moreover, the second position for both statements indicates that they extremely agree with them. Only $8.3 \%$ (3 out of 36 ) and $13.9 \%$ (5 out of 36 ) respectively show their moderate agreement. Therefore, the data, once again, confirm that all students approve the notion of both statements.

The pronunciation challenges faced by the students may differ from one another. From the interview, there are some obstacles students often encounter. The first one refers to word stress in English, which does not exist in Bahasa.

"I think English is difficult because they have stress. Meanwhile, we don't have such stress in Bahasa."

(Student \#1)

The second obstacle is the frequent dissimilarity between word spelling and its pronunciation.

"For some (English) words, their spelling is different from their pronunciation. For example, the term 'eight'. It has ' $g$ ' letter there; but why on earth it becomes silent when pronounced. It often makes me dizzy."

(Student \#3)

Another frequent hindrance is that students are not familiar with some English sounds.

"They (English) have sounds that we (Indonesian) don't. It challenges me to learn more so that native speakers will understand my pronunciation better"

(Student \#5)
"Every time I say 'selamat ulang tahun' (happy birthday) to my friend, it always sounds like 'selamat hari burung' (happy bird-day). Honestly, I have a problem with English 'th' sounds. I don't recognize it in my Bahasa."

(Student \#6)

From the result, it can be assumed that all of the hurdles faced by students in learning English pronunciation are mostly due to the distinct phonological systems between English and Bahasa as the students' first language. Some phonological aspects in English are absent in Bahasa, such as word stress and several consonant sounds. The finding is in line with many of the previous studies which reveal that the difference of the phonological system between both languages plays a significant role in the student difficulty when learning pronunciation (Donal, 2016; Lestiono and Gusdian, 2017; Gusdian and Lestiono, 2018; Anam, 2018; Sundari, 2018; Andi-Pallawa and Alam, 2013).

\section{Student Perception on the Use of Hijaiyah Sounds}

The discussion on the student perception on Hijaiyah sounds is divided into (1) how familiar they are with the sounds and (2) how they perceive the employment of the Hijaiyah sounds in their English pronunciation class.

\section{Student Perception on Hijaiyah Sounds}

Perception pertaining to the student familiarity with Hijaiyah sounds, Table 2 explains the result for each statement.

TABLE 2 | Student Perception of their familiarity with Hijaiyah

\begin{tabular}{llllll}
\hline Statement & $\mathbf{1}$ & $\mathbf{2}$ & $\mathbf{3}$ & $\mathbf{4}$ & $\mathbf{5}$ \\
$\begin{array}{l}\text { Most Indonesian stu- } \\
\text { dents have studied }\end{array}$ & $0 \%$ & $0 \%$ & $11.1 \%$ & $25 \%$ & $63.9 \%$ \\
reciting Quran & & & & & \\
$\begin{array}{l}\text { Indonesian students } \\
\text { are familiar with }\end{array}$ & $0 \%$ & $0 \%$ & $8.3 \%$ & $25 \%$ & $66.7 \%$ \\
Hijaiyah & & & & & \\
\hline
\end{tabular}

From the findings, the students admit that most Indonesian students are familiar with reciting Quran. More than half of the respondents (63.9\%) extremely agree with the first statement. Besides, the rest of the respondents also show positive answers (with $25 \%$ and $11,1 \%$ for scale 4 and 3 respectively). This finding is supported with the result from the interview saying that they have learned the Quran for quite a longtime.mostly since they were still little kids. Such a fact, hence, supports the second notion saying that Indonesian students are well-acquainted with Hijaiyah, in their everyday life, through reciting Quran. 
"I have learned to recite the Quran since I was a kid."

(Student \#2)

"I long as I can recall, I've been reciting the Quran for 15 years, since I was around four years old."

(Student \#3)

This can be perceived from the consistency shown in the students' answers for the second statement in Table 2. Once again, the majority of the respondents extremely agree with the notion. The other respondents also imply their approval to the idea; besides, none of them disagree their approval to the idea; besides, none of them disagree students' answers for the second statement in Table 2. Once again, the majority of the respondents extremely agree with the notion. The other respondents also imply their approval to the idea; besides, none of them disagree with it (no one chooses scale 1 and 2 as the indicator of disapproval). This finding is also strengthened with the interview results. The students claim that they are fluent enough in pronouncing Hijaiyah as they grow up learning to read them.

\footnotetext{
"Hijaiyah has been a part of me. I've learned about it since I was a kindergartner. Now, I am fluent in it, I mean only in pronouncing Hijaiyah-not speaking."
}

(Student \#4)

\begin{tabular}{|c|c|c|c|c|}
\hline Statement & 1 & 2 & 3 & 5 \\
\hline $\begin{array}{l}\text { Some English sounds } \\
\text { are pronounced simi- } \\
\text { larly to some Hijaiyah } \\
\text { sounds }\end{array}$ & $0 \%$ & $0 \%$ & $5.6 \%$ & $66.7 \% 27.8 \%$ \\
\hline $\begin{array}{l}\text { English and Arabic } \\
\text { share the same sounds }\end{array}$ & $0 \%$ & $2.8 \%$ & $11.1 \%$ & $61.1 \% 25 \%$ \\
\hline $\begin{array}{l}\text { Students can pro- } \\
\text { nounce English more } \\
\text { accurately when using } \\
\text { Hijaiyah sounds }\end{array}$ & $0 \%$ & $0 \%$ & $5.6 \%$ & $22.2 \% 72 \%$ \\
\hline $\begin{array}{l}\text { Hijaiyah sounds can } \\
\text { help Indonesian stu- } \\
\text { dents to learn English } \\
\text { pronunciation }\end{array}$ & $0 \%$ & $0 \%$ & $2.8 \%$ & $33.3 \% 63.9 \%$ \\
\hline
\end{tabular}

In Table 3, it is observed that the majority of the students show affirmative answers in the scale of 4 for the first and the second statements. Besides, the other students also show their strong agreement as $27.8 \%$ and $25 \%$ respectively choose scale 5 , and fewer people moderately agree with both first and second statements. After being taught using Hijaiyah sounds, the students are more aware that some consonant sounds in Hijaiyah, such as $/ \theta /, /$ $/$, and $/ \int /$, are pronounced the same. Therefore, it explains their positive replies as displayed in the Table 3. Furthermore, the students acknowledge that learning Hijaiyah in their English pronunciation class raises their understanding of how two utterly different languages can share some similarities in terms of their linguistic aspects.

\section{"I 100\% agree that Hijaiyah sounds for some consonants are similar to English sounds. It also makes me realize that Arabic and English, which come from two completely dif- ferent languages, can still have some things in common."}

\section{(Student \#5)}

These results amplify Lestiono and Gusdian (2017), who argue that Indonesian EFL students are knowledgeable about several phonological aspects of Arabic through their acquaintance with Hijaiyah. It is due to the fact that most Indonesians are Muslims, who are obliged to be able to recite the Quran.

\section{Student Perception of the Use of Hijaiyah Sounds to Facilitate English Pronunciation}

Table 3 depicts how the students perceive the employment of Hijaiyah sounds to assist them in learning English pronunciation. Their answers reflect their experience being taught using several Hijaiyah sounds to achieve several targeted consonant sounds in English.
As the students acknowledge that Hijaiyah and English sounds share some similarities, the students admit that such a resemblance may also facilitate their English learning. Therefore, most of them extremely agree with the next two statements saying that Hijaiyah sounds help Indonesian students to pronuncistatements for number 3 and 4 as most of the students choose scale 5 .

From the interview, it is also revealed that by recalling their knowledge in Hijaiyah consonant sounds, they can apply it in their English pronunciation learning. Another student also replies that Hijaiyah makes re-activate her knowledge of certain English sounds; thus, it can improve her accuracy in pronouncing English words. ation English words better. Consistencies are indicated in both 
"When the lecturer explained that some sounds like $/ \theta /, / \partial /$ are present in Hijaiyah, I started to realize that it can help me to pronounce some English words like 'mother', and 'birth' correctly."

(Student \#6)

"Before the Hijaiyah material, I often pronounced words with 'th' sounds wrongly because I thought I wasn't familiar with the sound. But, now I've realized that actually, I have it in my linguistic competence."

(Student \#7)

The results as mentioned above support the findings in Gusdian and Lestiono (2018); they reveal that from the observation, the students can pronounce some targeted English words correctly as compared to the condition before the introduction of Hijaiyah sounds.

\section{Student Perception of the Implementation of Hijaiyah to Teach English Pronunciation}

The last discussion about whether or not Hijaiyah sounds can continuously be applied as one of the crucial materials in the pronunciation class for Indonesian EFL learners is illustrated inTable 4.

TABLE 4 | Student Perception of the Implementation of Hijaiyah to Teach English Pronunciation

\begin{tabular}{|c|c|c|c|c|c|}
\hline Statement & 1 & 2 & 3 & 4 & 5 \\
\hline $\begin{array}{l}\text { English teachers in } \\
\text { Indonesia can always } \\
\text { incorporate Hijaiyah } \\
\text { sounds to teach English } \\
\text { pronunciation }\end{array}$ & $0 \%$ & $0 \%$ & $5.6 \%$ & $30.6 \%$ & 63.9 \\
\hline $\begin{array}{l}\text { Hijaiyah should be used } \\
\text { by English teachers when } \\
\text { teaching English pronun- } \\
\text { ciation }\end{array}$ & $0 \%$ & $0 \%$ & $8.3 \%$ & $33.3 \%$ & 58 \\
\hline
\end{tabular}

The results in Table 4 depicts the students' agreement for English teachers to infuse Hijaiyah sounds in their pronunciation class. Consistent answers are seen in which more than half of the respondents respond that they exceptionally agree with each of the statements, respectively. In addition, there are approximately 12 people who choose scale $4(30,6 \%$ and $33.3 \%$ for both statements correspondingly). And, only fewer than $10 \%$ of the total respondents somewhat agree with the statements. The results are also reinforced with the interview result, which exposes their supports to the idea. The students believe that using Hijaiyah in teaching English pronunciation can be beneficial, especially for improving students' accuracy in speaking. As a matter of fact, many Indonesian students often make errors in pronouncing words containing sounds like $/ \theta$
/, / $/ /$, and $/ \int /$. By raising their awareness through Hijaiyah sounds, such an issue can be minimized.

"Many of my classmates and I often mispronounce some English words.After the lecturer explained about the similarity between someHijaiyah and English sounds, we can finally pronounce the words correctly. I hope by continuing the implementation of Hijaiyah, the pronunciation issue will decrease."

(Student \#1)

Despite all of the supportive replies, one student indeed expresses his doubt. In his opinion, the implementation of Hijaiyah sounds may become more challenging for nonMuslim students. It is due to their unfamiliarity with the Arabic sounds.

"It's good to use Hijaiyah in our pronuncia-
tion activities. But, Iam not sure if it will work
to, let's say, Christian students. They never
learn Hijaiyah."

(Student \#2)

The above-mentioned finding is slightly different from Gusdian and Lestiono (2019), who imply from their observation that non-Muslim students (or students lacking the Hijaiyah/Arabic exposure) can still keep up with the lesson on Hijaiyah. It is because they are surrounded by the Muslim community; thus, they more or less own some amount of knowledge about the language. Yet, further study is needed to clarify this issue.

\section{CONCLUSION}

In conclusion, this study has proven that the implementation of Hijaiyah sounds in teaching English pronunciation is perceived positively by the students at the university level. All of the findings mainly suggest that students perceive that English pronunciation is somewhat problematic as it has some different features from those in their native language. Therefore, Hijaiyah sounds are perceived as an applicable bridge to facilitate their English pronunciation learning. However, this study has not covered an investigation on how students with limited Arabic exposure perceive the use of Hijaiyah in an English class. Thus, a further study is needed to dig out whether or not Hijaiyah sounds are sufficient to be implemented to teach students with limited Arabic exposure.

\section{ACKNOWLEDGMENTS}

The researchers would thank the reviewers for their suggestions and recommendations towards the betterment of this paper. 


\section{REFERENCES}

Anam, M. K. (2018). Thai and Indonesian English Students' Problems in Pronouncing English Fricative and Affricate Sounds: A Case Study in IAIN Kediri. In and others, editor, Fourth Prasasti International Seminar on Linguistics (Prasasti 2018). Atlantis Press.

Andi-Pallawa, B. and Alam, A. F. A. (2013). A Comparative Analysis between English and Indonesian Phonological Systems. International Journal of English Language Education, 1(3):103-129.

Atmowardoyo, H. (2018). Research Methods in TEFL Studies : Descriptive. Journal of Language Teaching and Research, 9(1):197-204.

Dardjowidjojo, S. (1978). Sentence patterns of Indonesian. University of Hawaii Press.

Donal, A. (2016). Indonesian Students' Difficulties in Pronouncing English Dipthongs. Journal of English Education, 2(2):55-62.

Gusdian, R. I. and Lestiono, R. (2018). The use of Arabic consonant sounds to arrive at English pronunciation: A Case Study on Indonesian EFL students in tertiary level. Erudio Journal of Educational Innovation, 5(2):1-9.

Gusdian, R. I. and Lestiono, R. (2019). Cater for proper English pronunciation in the primary school level : put to use Arabic consonants. 5(2):254-261.

Lestiono, R. and Gusdian, R. I. (2017). Arriving at English pronunciation by means of Arabic consonant sounds: A case study on EFL students in Indonesian context. 7th International Conference on Literature, Humanities, Social Sciences and Education (LHSSE-2017, pages 106-117.

Sundari, W. (2018). The Difficulties of Learning English for the Basic English Learners. Journal of Cultural, Literary, and Linguistic Studies, 2(1):34-41.

Conflict of Interest Statement: The authors declare that the research was conducted in the absence of any commercial or financial relationships that could be construed as a potential conflict of interest.

Copyright (C) 2020 Gusdian and Lestiono. This is an open-access article distributed under the terms of the Creative Commons Attribution License (CC BY). The use, distribution or reproduction in other forums is permitted, provided the original author(s) and the copyright owner(s) are credited and that the original publication in this journal is cited, in accordance with accepted academic practice. No use, distribution or reproduction is permitted which does not comply with these terms. 